DOI 10.37882/2223-2982.2020.04-2.17

\title{
ВНЕШНЯЯ ПОЛИТИКА ИСЛАМСКОЙ РЕСПУБЛИКИ ИРАН В УРЕГУЛИРОВАНИИ НАГОРНО-КАРАБАХСКОГО КОНФЛИКТА
}

\section{FOREIGN POLICY OF THE ISLAMIC REPUBLIC OF IRAN IN THE SETTLEMENT OF THE NAGORNO-KARABAKH CONFLICT \\ A. Egikov}

Summary: The relevance of scientific research is to study the influence of Iran's mediation in resolving the conflict between Armenia and Azerbaijan over the Nagorno-Karabakh region. The history of the formation of contradictions between these countries over disputed territories is traced, the causes of the conflict are identified. In order to formulate a general picture of the reasons for Iran's interference in this armed confrontation, a comparative analysis of Tehran's foreign policy has been carried out since the overthrow of the Shah's regime in 1979 and right up to the assumption of the powers of President A. Rafsanjani. In this regard, the international situation of Armenia and Iran in the considered chronological period is analyzed, the reasons for their close cooperation in various respects are revealed. The scientific novelty of the study consists in revealing the reasons for the active presence of Iran in the settlement of this conflict. The role of the South Caucasus and its member states for Tehran's foreign policy strategy is analyzed.

Keywords: Armenia, Azerbaijan, Iran, Turkey, conflict settlement, Nagorno-Karabakh.

\author{
Егиков Артём Александрович, \\ Аспирант, Северо-Осетинский государственный \\ университет им. К.Л. Хетагурова; учитель, МОУ СОШ \\ №15 им. Героя Советского Союза Х.З. Мильдзихова, г. \\ Владикавказ \\ araxxxbrat777@rambler.ru
}

Аннотация: Актуальность научного исследования заключается в изучении влияния посреднической деятельности Ирана в урегулировании конфликта между Арменией и Азербайджаном за регион Нагорного Карабаха. Прослеживается история формирования противоречий между этими странами за спорные для них территории, выявляются причины конфликта. Для формирования общей картины причин вмешательства Ирана в данное вооруженное противостояние, проведен сравнительный анализ внешней политики Тегерана с момента свержения шахского режима в 1979 г. и вплоть для вступления в полномочия президента А. Рафсанджани. В этой связи анализируется международное положение Армении и Ирана в рассматриваемый хронологический период, выявляются причины их тесного сотрудничества в различных отношениях. Научная новизна исследования состоит в раскрытии причин активного присутствия Ирана в урегулировании данного конфликта. Анализируется роль Южного Кавказа и государств, входящих в него, для внешнеполитической стратегии Тегерана.

Ключевые слова: Армения, Азербайджан, Иран, Турция, урегулирование конфликта, Нагорный Карабах.

жанский революционный комитет своей декларацией признал Зангезур и Нахичевань частью Армянской ССР, а Карабаху предоставил право на самоопределение. Думается, данное решение поставило регион в весьма неопределенное положение.

Советскому государству в конечном итоге пришлось законодательно закрепить его за Азербайджанской ССР, учитывая сложную международную обстановку, заключавшуюся в дипломатической блокаде со стороны мирового сообщества. Похожая ситуация была в Турции, где был установлен режим М. Кемаля. Исходя из этого, между ними сложились дружественные взаимоотношения. Благосклонная позиция Анкары по отношению к Азербайджану, склонила Москву к передаче Нагорного Карабаха в пользу Баку. Данное решение было подтверждено постановлением пленума Кавбюро ЦК РКП (б) от 3 июня 1921 г., однако окончательное решение было принято пленумом Кавбюро ЦК РКП (б), состоявшимся 5 июля того же года: «Нагорный Карабах оставить в пределах Азербайджанской ССР, предоставив ему широкую областную автономию». [3, с. 292-305]. Несомненно, это вызвало недовольство со стороны армянского населения региона. Ситуация оставалась неизменной вплоть 
до 1991 г.

В период нахождения у власти М. Горбачева вопрос территориальной принадлежности Карабаха обострился. Политика «гласности», проводимая им, спровоцировала те центробежные силы, выступавшие за отделение спорной территории от Азербайджанской ССР. Последний же приветствовал сохранение положения «статускво» в регионе.

Практически одновременно с распадом СССР в 1991 г., идеологическое противостояние за будущее Карабаха перешло в открытую вооруженную фазу между Ереваном и Степанакертом с одной стороны, и Баку с другой. Как отметил С. Корнелл: «Из всех кавказских конфликтов карабахский конфликт имеет наибольшее стратегическое и общерегиональное значение. Этот конфликт - единственный на территории бывшего Советского Союза, в который непосредственно вовлечены два независимых государства. Более того, в конце 1990-х гг. Карабахский конфликт способствовал формированию на Кавказе и вокруг него противостоящих друг другу группировок государств».[6, р. 1-3]

Вооруженное противостояние шло с переменным успехом для каждой из сторон. Широкое распространение получило участие в конфликте наемных отрядов. Турецкие подразделения так же были замечены на данном театре военных действий. [2, с. 107-136]

Несмотря на численное и техническое преимущество Азербайджана, последним было допущено ряд стратегических ошибок, приведших к победе армянской стороны. Успехи Еревана и Степанакерта привлекли пристальное внимание европейских стран, России и Ирана, были приняты меры к остановке военных действий и выработке «дорожной карты» урегулирования Нагорно-Карабахского конфликта. При посредничестве Минской группы ОБСЕ был подписан Бишкекский протокол 5 мая 1994 г. между участниками вооруженного противостояния. С тех пор ситуация в регионе характеризуется положением «ни мира, ни войны».

Исламская республика Иран приняла активное участие в урегулировании данного конфликта. Прежде чем анализировать данный аспект, следует проследить эволюцию внешнеполитической стратегии Тегерана с момента свержения шахского режима и вплоть до президентства А. Рафсанджани. Шиитское духовенство, пришедшее к власти в 1979 г. в результате исламской революции имело своё видение на международное положение Ирана. Ориентация на исламские государства, враждебное отношение к СССР и США были характерными чертами внешнеполитической стратегии Ирана в рассматриваемый период. [1, с. 450-499]
Смерть Р. Хомейни в 1989 г. и избрание на пост президента А. Рафсанджани, более прагматичного в своей политике, видоизменили внешнеполитическую доктрину Тегерана. Начался процесс нормализации дипломатических отношений с множеством стран, в приоритете было установление союзнических отношений в первую очередь с соседними государствами. [1, с. 520-525]

Южный Кавказ представлял для Ирана прекрасную возможность закрепления своей внешнеполитической доктрины. Это сопровождалось развитием дипломатических взаимоотношений с государствами данного региона. Особенно это было необходимо Армении, которая в условиях противостояния с Азербайджаном за Нагорный Карабах осталась практически в полной изоляции. Установление союзнических взаимоотношений шиитского Ирана с христианской Арменией в противовес Азербайджану явилось доказательством того, что Тегеран решительно отошел от прежних установок во внешней политике. Однако это не встретило понимания в Баку.

В условиях проживания в северных провинциях Ирана больших этнических групп армян и азербайджанцев, иметь в непосредственной близости от них вооруженный конфликт между Арменией и Азербайджаном, было крайне опасно для территориальной целостности Тегерана. Из этого следует вывод, что для Ирана, важно было претендовать на роль дипломатического арбитра при решении конфликта

После вступления Азербайджана в СБСЕ, вооруженное столкновение в Нагорном Карабахе стало привлекать внимание не только региональных стран, но мировых, которые могли под видом урегулирования конфликта вносить свои коррективы в политическую жизнь Армении, НКР и Азербайджана. В этой связи следует указать про стремление Турции занять то геополитическое пространство, которое образовалось после распада СССР. В частности, Анкара планировала объединить в единое территориальное пространство все тюркские страны с исламской идеологией. Нахождение же Нагорного Карабаха в составе Армении не позволяло реализовать данную идею, ввиду отсутствия прямого сообщения с Азербайджаном. Для Ирана претворение в жизнь турецкого плана означало бы полную изоляцию от Южного Кавказа. Так же нейтралитет Тегерана в урегулировании конфликта, в котором участвует шиитский Азербайджан, мог негативно сказаться на общественных настроениях внутри страны.

В рамках реализации своей политики в Нагорном Карабахе, в Баку 25 февраля 1992 г. пребывает министр иностранных дел Ирана А. Велаяти. Он предлагает конфликтующим сторонам подписать договор о перемирии, что и произошло 26 февраля. Боевые действия 
прекращались с 27 февраля по 1 марта. Несмотря на это, армянские вооруженные силы свели на нет дипломатические успехи Ирана, заранее спланировали наступление на Ходжалы, являвшимися «воротами» в НКР, имея важное стратегическое значение для обеих сторон конфликта. [8, р.6] Армянская сторона вследствие успешного наступления на азербайджанские позиции добилась значительного преимущества.

Иранские дипломаты не остановились в своих миротворческих намерениях, и снова предложили Еревану и Баку сесть за стол переговоров, но уже на территории своей страны. В марте 1992 г. в Тегеране состоялась встреча глав Армении, Азербайджана и Нагорно-Карабахской республики, в ходе которой обсуждались мирные инициативы в данном конфликте. [7]

В мае 1992 г. Иран организовал второй раунд переговоров между Арменией и Азербайджаном, пригласив представителей последних в Тегеран. Они при посредничестве иранской стороны подписали «Совместное заявление глав государств в Тегеране», по результатам которой противоборствующие стороны обязывались организовывать на высшем уровне дипломатические встречи для решения сложившейся военной проблемы между двумя государствами. Так же по итогам переговоров Ирану удалось добиться разблокировки различных коммуникаций между ними и инициировать прекращение огня в зоне боевых действий. [4, с. 91-94]

Армянская сторона, спустя 5 часов после переговоров в Тегеране, начала наступление по захвату населенных пунктов Лачин и Шуша. Данным событием были сведены на нет дипломатические усилия Ирана в урегулировании конфликта. Его присутствие вплоть до конца войны было относительно минимальным, уступив дипломатии других государств. Ситуация в Нагорном Карабахе перешла под полный контроль Минской группы ОБСЕ. Последняя начала осуществлять активную посредническую деятельность по примирению сторон. Логичным завершением данных действий явилось подписание Бишкекского протокола в 1994 г. Однако вопрос территориальной принадлежности данного региона остается открытым, что не может не создавать определенной напряженности между Ереваном и Баку на современном этапе. Постоянное нарушение режима перемирия, установленное после подписания вышеуказанного протокола, обостряет сильнее с каждым разом данную проблему, что требует мониторинга третьих стран в деле поддержания мира в регионе.

\section{ЛИТЕРАТУРА}

1. Алиев С.М. История Ирана. ХХ век. М: ИВ РАН - Крафт+, 2004. 648 с.

2. Демоян Г. Турция и Карабахский конфликт. Ереван: Проспектус, 2006. 255 с.

3. Нерсисян М.Г. История армянского народа с древнейших времен до наших дней. Ереван: Издательство Ереванского университета, 1980.460 с.

4. Саркисян М. Нагорный Карабах: Война и политика. Война в Нагорном Карабахе и внутренний конфликт в армянском обществе. Ереван: Армянский центр стратегических и национальных исследований, 2010. 219 с.

5. Bradshaw M.J. Contemporary World Regional Geography: Global Connections, Local Voices. N. Y: Mcgraw-Hill (Tx), 2004. 640 p.

6. Cornell E.S. The Nagorno-Karabakh Conflict. Uppsala: Department of East European Studies, 1999. 164 p.

7. Iran's Role as Mediator in the Nagorno-Karabakh Crisis. [Электронный ресурс]. - Режим доступа: http://poli.vub.ac.be/publi/ContBorders/eng/ch0701.htm (дата обращения: 27.03.2020)

8. Panico C., Rone J., Human Rights Watch / Helsinki. Azerbaijan: Seven Years of Conflict in Nagorno-Karabakh. N.Y: Human Rights Watch, 1994. 118 p.

(c) Егиков Артём Александрович (araxxxbrat777@rambler.ru). 